\title{
PENGARUH PENAMBAHAN TINTA CUMI-CUMI (Loligo sp.) TERHADAP KANDUNGAN GIZI, FISIK, SENSORIK, DAN ANTIOKSIDAN MIE BASAH
}

Effect of The Addition of Squid Ink (Loligo sp.) To Nutritional, Sensory, Physical, and Antioxidant Content of Wet Noodles

\author{
Nur Hutriani1, Tamrin², Suwarjoyowirayatno1 \\ 1Jurusan Teknologi Hasil Perikanan, Fakultas Perikanan dan Ilmu Kelautan Universitas Halu Oleo, Kendari, \\ Sulawesi Tenggara, Indonesia \\ 2Jurusan Ilmu dan Teknologi Pangan, Fakultas Pertanian Universitas Halu Oleo, Kendari, Sulawesi Tenggara, \\ Indonesia \\ *Email korespondensi: nurhutriani15@gmail.com (Telp: +6281283637108) \\ Diterima: 27 September/ Disetujui 30 Oktober 2019
}

Cara sitasi: Hutriani N, Tamrin, Suwarjoyowirayatno. 2019. Pengaruh penambahan tinta cumi-cumi (Loligo sp.) terhadap kandungan gizi, fisik, sensorik, dan antioksidan mie basah. Jurnal Fish Protech. 2(2):210-217.

\section{ABSTRACT}

The aims of this study was to determine the effect of adding squid ink (Loligo sp.) To sensory, physical and antioxidant properties. This study used a Completely Randomized Design (CRD) consisting of five treatments addition of squid ink with three replications, namely N0 (0\%), N1 (1\%), N2 (1, 5\%), N3 (2\%), and N4 (2.5\%). Data from observations were analyzed using ANOVA (Analysis Of Variance) at $95 \%$ level, if there is a real difference $(P>0.05)$, further tests were carried out with a DMRT (Duncan Multiple Range Test) test at $95 \%$ significance level. The results obtained showed that the addition of squid ink have a real effect on sensory values which included taste, aroma, and texture but the sensory value of the color have no significant effect. Based on the sensory test, the best treatment test is done with the Effectiveness Index method of the best treatment results being the basis for testing the nutritional content, and antioxidants. The test results of nutrient content, antioxidants, and squid ink (Loligo sp.) Wet noodles in the best treatment were found in the N2 (water content of $56.93 \%$, protein content $24.85 \%$, ash content 0.5 , and carbohydrate content $15.86 \%$ ) and antioxidant testing (noodles without squid ink (Loligo sp.) 327.18 ppm, noodles with the addition of squid ink (Loligo sp.) $316.89 \mathrm{ppm}$ and squid ink (Loligo sp. ) 267.90 ppm). The physical test results in the treatment of 10\% N0, N1 23.33\%, N2 $30 \%$, N3 40\%, and N4 56.67\%.

Keywords: Antioxidants, nutritional content, Loligo sp., physical, and sensory.

\section{ABSTRAK}

Tujuan penelitian ini adalah untuk mengetahui pengaruh penambahan tinta cumi-cumi (Loligo sp.) terhadap sifat sensorik, fisik dan antioksidan. Penelitian ini menggunakan Rancangan Acak Lengkap (RAL) yang terdiri dari lima perlakuan dan tiga kali ulangan yaitu N0 (penambahan tinta cumi-cumi 0\%), N1 (penambahan tinta cumi-cumi 1\%), N2 (penambahan tinta cumi-cumi 1,5\%), N3 (penambahan tinta cumi-cumi 2\%), dan N4 (penambahan tinta cumi-cumi 2,5\%). Data hasil pengamatan dianalisis menggunakan ANOVA (Analysis Of Variance) pada taraf 95\%, apabila terdapat beda nyata $(P>0,05)$ maka dilakukan uji lanjut dengan uji DMRT (Ducan Multiple Range Test) pada taraf nyata 95\%. Hasil penelitian yang diperoleh menunjukkan bahwa penambahan tinta cumi-cumi memberikan pengaruh nyata terhadap nilai sensorik yang meliputi rasa, aroma, dan tekstur tetapi pada nilai sensori warna memberikan pengaruh tidak nyata. Berdasarkan uji sensorik selanjutnya dilakukan uji perlakuan terbaik dengan metode Indeks Efektivitas hasil perlakuan terbaik menjadi dasar untuk uji kandungan gizi, dan antioksidan. Hasil uji kandungan gizi, antioksidan, dan tinta cumi-cumi (Loligo sp.) mie basah pada perlakuan tebaik terdapat pada perlakuan N2 (kadar air 56,93\%, kadar protein 24,85\%, kadar abu 0,5, dan kadar karbohidrat 15,86\% ) dan pengujian antioksidan (mie tanpa tinta cumi-cumi (Loligo sp.) 327,18 ppm, mie dengan penambahan tinta cumi-cumi (Loligo sp.) 316,89 ppm dan tinta cumi-cumi (Loligo sp.) 267,90 ppm). Hasil pengujian fisik pada perlakuan N0 10\%, N1 23,33\%, N2 30\%, N3 40\%, dan N4 56,67\%.

Kata kunci: Antioksidan, fisik, kandungan gizi, Loligo sp., dan sensorik. 


\section{PENDAHULUAN}

Menurut Direktorat Jendral Perikanan Tangkap (2011), potensi sumber daya perikanan khususnya cumi-cumi (Loligo sp.) di Selat Karimata dan sekitarnya mencapai 2,7 ribu ton/tahun merupakan peluang bagi perikanan tangkap Indonesia agar dapat dimanfaatkan dengan baik (Sudjoko 1988). Cumi-cumi mengandung energi sebesar 75 kilokalori, protein 16,1 $\mathrm{g}$, karbohidrat $0,1 \mathrm{~g}$, lemak $0,7 \mathrm{~g}$, kalsium $32 \mathrm{mg}$, fosfor $200 \mathrm{mg}$, dan zat besi1,8 mg.

Menurut Okozumi dan Fujii (2000), melano protein tinta cumi-cumi mengandung asam amino esensial yang dominan berupa lisin, leusin, arginin dan fenilalanin. Kadar asam amino non esensial yang dominan adalah asam glutamat dan asam aspartat. Tinta cumi-cumi mengadung antioksidan yang terdapat pada melanin tinta cumi-cumi.

Tinta cumi-cumi (Loligo sp.) dapat juga berfungsi sebagai antikanker, anti tumor, dan antibakteri yang merupakan bakteri pembusuk. Bakteri yang dimaksud seperti E. coli, Pseudomonas aeruginosa, dan Staphylococcus epidermidis. Menurut penelitian (Nair et al., 2011), menyebutkan bahwa tinta cumi-cumi memiliki aktivitas antibakteri. Berdasarkan manfaat tinta cumi-cumi (Loligo sp.) yang cukup besar, sehingga dapat dimanfaatkan dalam pembuatan mie.

Mie merupakan produk yang sangat digemari oleh masyarakat Indonesia, baik anak-anak, remaja maupun lanjut usia. Namun kandungan gizi yang terdapat dalam mie belum menunjang nilai gizi yang diperlukan oleh manusia, terutama anak-anak yang

\section{Rancangan Penelitian}

Metode penelitian ini menggunakan Rancangan Acak Lengkap (RAL), yaitu dengan perlakuan penambahan konsentrasi tinta cumi-cumi, yang terdiri dari 5 taraf yaitu $0 \%, 1 \%, 1,5 \%, 2 \%, 2,5 \%$. Masingmasing perlakuan diulang sebanyak 3 kali, sehingga diperoleh 15 unit percobaan. Formulasi (komposisi) bahan dalam pembuatan mie basah dengan penambahan tinta cumi-cumi (Loligo sp.) (Agusandi et al., 2013) yang dimodifikasi. sangat membutuhkan asupan gizi untuk pertumbuhan dan perkembangan tubuhnya.

Menurut Agusandi et al., (2013), menyatakan bahwa mie yang di campurkan dengan tinta cumi-cumi (Loligo sp.) mempunyai kandungan nutrisi cukup baik di antaranya provitamin A 169,89, kadar protein $7,109 \%$, kadar karbohidrat $14,85 \%$, kadar air $52,57 \%$, dan kadar abu $0,34 \%$. Dengan penambahan tinta cumi-cumi (Loligo sp.) didalam mie basah dapat menambah kandungan zat gizi dan antioksidan yang dapat mencegah kerusakan sel.

\section{METODE PENELITIAN}

\section{Alat dan Bahan}

Peralatan yang digunakan dalam penelitian ini ada dua macam yaitu alat untuk pengolahan mie basah dan alat untuk analisis. Alat pengolahan meliputi baskom plastik, sarung tangan (plastik), panci stainless, kompor gas, perangkat pencetak mie, timbangan analitik, pisau stainless. Alat untuk analisis gizi dan antioksidan chromameter, cawan porselen, erlenmeyer, hotplate, corong, spatula, gelas beaker, oven, dan pipet tetes.

Bahan-bahan yang digunakan dalam penelitian ini adalah Bahan utama adalah tepung terigu, dan tinta cumi-cumi (Loligo sp.) yang diperoleh dari TPI Kendari. Bahan kimia untuk analisis gizi dan antioksidan adalah $\mathrm{H}_{2} \mathrm{SO}_{4}, \mathrm{NaOH}$, kertas saring 0,8 $\mathrm{mm}$, aquadest, kertas lakmus, $\mathrm{K}_{2} \mathrm{SO}$, alkohol $95 \%$, dan DPPH. 
Tabel 1. Formulasi bahan pembuatan mie basah dengan penambahan tinta cumi-cumi

\begin{tabular}{llllll}
\hline Bahan & N0 & N1 & N2 & N3 & N4 \\
\hline Tinta cumi-cumi (\%) & 0 & 1 & 1,5 & 2 & 2,5 \\
Tepung terigu $(\mathrm{g})$ & 200 & 200 & 200 & 200 & 200 \\
Garam $(\mathrm{g})$ & 2 & 2 & 2 & 2 & 2 \\
Telur $(\mathrm{g})$ & 20 & 20 & 20 & 20 & 20 \\
Soda kue $(\mathrm{g})$ & 1 & 1 & 1 & 1 & 1 \\
Air $(\%)$ & 15 & 15 & 15 & 15 & 15 \\
\hline
\end{tabular}

\section{Prosedur Penelitian}

Prosedur pada penelitian ini adalah sebagai berikut:

1. Pengambilan tinta cumi-cumi (Agusandi et al., 2013)

a. Cumi-cumi utuh yang masih segar disiapkan (kepala dan kantong tinta).

b. Kantong tinta diambil dari bagian tubuh cumicumi, kemudian dipisahkan pada wadah yang bersih.

c. Kantong tinta cumi-cumi diambil dengan cara dipencet (diberi tekanan) secara perlahanlahan, kemudian tinta yang keluar ditampung dalam sebuah wadah bersih, (lampiran 1).

\section{Pengolahan Mie Basah}

Pengolahan mie basah menurut Mujiono (2010), dalam Pribadi (2011), adalah sebagai berikut:

a. Tepung terigu dan telur dimasukkan sesuai dengan komposisi kedalam wadah pengadonan, diadoni hingga telur dan terigu tercampur rata.

b. Cairan tinta cumi-cumi ditambahkan sesuai dengan perlakuan $(0 \%, 1 \%, 1,5 \%$, dan $2 \%$, $2,5 \%$ ) dan air $15 \%$ yang telah ditambahkan garam sebanyak $2 \%$, diadoni hingga kalis, ditandai dengan tidak lengketnya adonan dan juga kelihatan mengkilat.

c. Adonan yang dihasilkan kemudian dipres dengan perangkat pencetak mie.

d. Lembaran mie yang telah dipres lalu dicetak membentuk untaian mi dengan menggunakan perangkat pencetak mie.

e. Untaian mie yang terbentuk dimasukkan ke dalam panci yang berisi air yang telah dididihkan sebanyak 1 liter kemudian direbus dengan penambahan minyak goreng sebanyak $5 \mathrm{ml}$.

f. Mie basah hasil rebusan ditiriskan dan didinginkan dalam baskom plastik. Mie basah yang dihasilkan kemudian dianalisis sesuai dengan parameter yang diamati, (lampiran 2).

\section{Variabel Yang Diamati}

Parameter yang akan dianalisis pada penelitian ini adalah kandungan gizi meliputi kadar air (AOAC 2005), kadar abu (AOAC 2005), kadar protein (AOAC 2005), karbohidrat (AOAC 2005) (perlakuan terbaik dari uji hedonik), sifat fisik mie basah yang mencangkup nilai pemanjangan (elogasi), sifat sensoris yang meliputi warna, aroma, tekstur, dan rasa dengan menggunakan uji hedonic (kesukaan) dan antioksidan (perlakuan terbaik dari uji hedonik).

\section{Uji Sensorik}

Pengujian sensori merupakan cara pengujian menggunakan indera manusia sebagai alat utama untuk menilai mutu produk. Uji sensori menggunakan uji kesukaan (hedonik), parameter yang diamati meliputi warna, aroma, tekstur dan rasa. Uji skor (scoring test) merupakan metode uji dalam menentukan tingkatan mutu produk berdasarkan skala angka 1 (satu) sebagai nilai terendah dan angka 5 (lima) sebagai nilai tertinggi dengan menggunakan lembar penilaian. Data yang diperoleh dari lembar penilaian ditabulasi dan ditentukan nilai mutunya dengan mencari hasil rerata pada setiap panelis pada tingkat kepercayaan 95\%. Penilaian dilakukan oleh 15 orang panelis yang sudah biasa mengkomsumsi mie (Meilgaard et al, 1999). 


\section{Analisis Data}

Data yang diperoleh dari penelitian ini dianalisis menggunakan analisis statistik non parametrik sidik ragam ANOVA Analisis of Varians jika terdapat perbedaan nyata dilakukan uji Ducan Multiple Range
Test (DMRT) dengan kepercayaan 95\% dan untuk penentuan perlakuan terbaik dalam penelitian dihitung menggunakan nilai indeks efektivitas De garmo et al., (1984) yang dimodifikasi oleh Susrini (2005).

e Test (DMRT) pada taraf kepercayaan $95 \%(a=0,05)$.

\section{HASIL DAN PEMBAHASAN}

\section{A. Sifat Sensori}

Tabel 1. Hasil analisis uji sensori

\begin{tabular}{ccccc}
\hline Perlakuan & Rasa & Aroma & Tekstur & Warna \\
\hline N0 & $4,68^{\mathrm{bc}} \pm 0,25$ & $4,33^{\mathrm{c}} \pm 0,29$ & $3,48^{\mathrm{ab}} \pm 0,23$ & $3,87 \pm 0,67$ \\
N1 & $4,30^{\mathrm{b}} \pm 0,30$ & $3,13^{\mathrm{b}} \pm 0,03$ & $3,08^{\mathrm{a}} \pm 0,06$ & $3,05 \pm 0,50$ \\
N2 & $5,00^{\mathrm{c}} \pm 0,00$ & $4,65^{\mathrm{c}} \pm 0,30$ & $3,57^{\mathrm{b}} \pm 0,39$ & $3,35 \pm 0,78$ \\
N3 & $4,68^{\mathrm{bc}} \pm 0,23$ & $2,48^{\mathrm{a}} \pm 0,18$ & $3,35^{\mathrm{ab}} \pm 0,22$ & $3,33 \pm 0,10$ \\
N4 & $2,67^{\mathrm{a}} \pm 0,58$ & $2,43^{\mathrm{a}} \pm 0,50$ & $3,50^{\mathrm{ab}} \pm 0,15$ & $3,83 \pm 0,58$ \\
\hline
\end{tabular}

Keterangan: Angka yang diikuti notasi huruf yang berbeda pada kolom yang sama menunjukkan berbeda nyata $(P<0,05)$

\section{Rasa}

Berdasarkan Tabel 1 pada sifat sensorik rasa, penilaian tertinggi hasil uji kesukaan diperoleh pada perlakuan N2 (tinta cumi-cumi (Loligo sp.) sebanyak $1,5 \%$ ) dengan nilai rata-rata 5,00 (suka), hal ini diduga karena tinta cumi-cumi memiliki sifat umami yang berasal dari asam glutamat sehingga rasa yang dihasilkan pada produk mie basah lebih gurih. Hal ini didukung dengan penelitian (Agusandi et al., 2013) bahwa hasil evaluasi sensorik terhadap mie basah dengan penambahan tinta cumi-cumi berpengaruh nyata terhadap rasa yang dihasilkan. Menurut Mukholik (1995), komponen yang terdapat dalam tinta cephalopoda berisi sejumlah bahan kimia dengan berbagai konsentrasi yang berbeda-beda, tergantung pada spesiesnya. Namun kandungan utamanya adalah melanin dan lendir, juga terdapat tirosin, dopamin, dan L-dopa serta sebagian kecil asam amino termasuk taurin, asam aspartat, asam glutamat, alanin, dan lisin.

\section{Aroma}

Berdasarkan Tabel 1, diketahui bahwa rerata nilai sensorik untuk aroma produk mie basah dengan penambahan tinta cumi-cumi (Loligo sp.) penilaian tertinggi dengan skor 4,33 pada perlakuan N0 tanpa penambahan tinta cumi-cumi (Loligo sp.). Penilaian uji sensorik aroma yang dilakukan oleh panelis pada produk mie basah yang dihasilkan diperoleh nilai berkisar 2,48 (agak suka) hingga 4,65 (suka) menunjukkan bahwa penambahan tinta cumi-cumi pada produk mie basah bepengaruh nyata. Hasil ini membuktikan bahwa semua perlakuan memiliki aroma yang berbeda.

Penilaian tertinggi hasil uji kesukaan panelis terhadap aroma tertinggi pada perlakuan N2 (tinta cumi-cumi (Loligo sp.) 1,5\%) dengan nilai rata-rata 4,65 (suka), hal ini diduga karena penambahan tinta cumi-cumi yang digunakan sangat sedikit sehingga tidak tercium aroma tinta cumi-cumi. Hal ini seiring dengan penelitian (Hutasoir et.,al 2015) menyatakan bahwa mie basah dengan penambahan tinta cumicumi sebagai pewarna alami, dimana aromanya terasa aroma tepung terigu mie basah sehingga panelis lebih menyukai tanpa penambahan tinta cumi-cumi. Karena pada tepung terigu tidak memiliki aroma sehingga konsumen cenderung lebih menyukai mie basah tanpa penambahan tinta cumi-cumi.

Winarno (1997), menyatakan bahwa dalam banyak hal, kelezatan makanan ditentukan oleh aroma atau bau dari makanan tersebut. Aroma yang menggugah selera akan menjadi parameter yang baik bagi konsumen untuk memilih produk tersebut. 


\section{Tekstur}

Berdasarkan Tabel 1 diperoleh bahwa, penilaian uji hedonik tekstur diperoleh skor tertinggi dengan rata-rata 3,57 pada perlakuan N2 dengan penambahan tinta cumi-cumi (Loligo sp.) sebanyak $1,5 \%$. Berdasarkan penilaian uji kesukaan pada tekstur menunjukkan bahwa penambahan tinta cumicumi pada produk mie basah berpengaruh nyata. Hal ini berbeda dengan penelitian (Agusandi et al., 2013) dalam penelitiannya mie basah dengan penambahan tinta cumi-cumi evaluasi sensoris yang dihasilkan tidak berpengaruh nyata terhadap tekstur mie basah. Menurut Kristina (2007), ciri-ciri tekstur mie basah yang baik adalah memiliki tekstur agak kenyal, dan tidak putus-putus. Menurut Mukholik (1995), tinta cumi-cumi tergolong alkali karena memiliki pH 7,8, sehingga apabila gluten pada tepung terigu berinteraksi dengan tinta cumi-cumi yang tergolong alkali akan menghasilkan mie basah dengan tekstur yang diharapkan yaitu mie basah matang memiliki tekstur yang kenyal dan elastis, mudah digigit, dan tidak terlalu lembek.

\section{Warna}

Berdasarkan Tabel 1, diperoleh bahwa pengujian hedonik pada warna skor tertinggi dengan rata- rata 3,87 pada perlakuan N0, tanpa penbahan tinta cumi-cumi (Loligo sp.). Penilaian uji kesukaan warna yang dihasilkan pada produk mie basah dengan penambahan tinta cumi-cumi tidak berbeda nyata. Hal ini diduga karena mie yang dihasilkan agak cenderung gelap sehingga panelis kurang menyukai. Menurut Dirjen Perikanan (1988), menyatakan bahwa tinta cumi-cumi terdapat kandungan pigmen hitam sehingga memberikan warna yang hitam kelam yang cemerlang. Penambahan tepung terigu selain memperbaiki elastisitas, sebagai bahan pengisi serta pengikat air, juga memberikan warna pada produk akhir olahan pangan (Takahashi et al., 1987). Menurut Winarno (2004), warna merupakan komponen yang sangat penting dalam menentukan kualitas atau derajat penerimaan dari suatu bahan pangan. Suatu bahan pangan yang dinilai enak dan teksturnya baik tidak akan dimakan apabila memiliki warna yang kurang sedap dipandang atau telah menyimpang dari warna yang seharusnya. Penentuan mutu suatu bahan pangan tergantung dari beberapa faktor, tetapi sebelum faktor lain diperhatikan secara visual faktor warna tampil lebih dulu untuk menentukan mutu bahan pangan.

\section{B. Sifat Fisik (Elongasi)}

Tabel 2. Uji fisik produk mie basah

\begin{tabular}{cc}
\hline Perlakuan & Elogasi (\%) \\
\hline N0 & 10 \\
N1 & 23,33 \\
N2 & 30 \\
N3 & 40 \\
N4 & 56,67 \\
\hline
\end{tabular}

Keterangan: Angka yang didampingi huruf berbeda pada kolom yang sama menunjukkan berbeda nyata $(P<0,05)$.

Berdasarkan hasil uji fisik pada produk mie dengan penambahan tinta cumi-cumu (Loligo sp.) menunjukkan bahwa, semua perlakuan penambahan tinta cumi-cumi (Loligo sp.) berpengaruh nyata terhadap elongasi mie basah. Hal ini di dukung dengan penelitian Haryadi (1999), menyatakan bahwa elongasi mie sangat dipengaruhi oleh kandungan gluten dalam tepung terigu, karena gluten dapat menghasilkan sifat kenyal dan elastis.

Berdasarkan pengukuran elogasi pada mie basah dengan penambahan tinta cumi-cumi (Loligo sp.), menunjukkan bahwa nilai tertinggi terdapat pada N4 (tinta cumi-cumi (Loligo sp.) 2,5\%). Hal ini diduga karena semakin banyak tinta yang di masukkan pada bahan pembuatan mie maka sifat elastis pada mie tersebut meningkat. Peningkatan elongasi ini diduga karena ada pengaruh dari kandungan protein dalam mie basah, menurut Winarno (1992), protein pada bahan pangan selain dapat meningkatkan nilai gizi juga dapat meningkatkan mutu fisik bahan menjadi liat, tidak mudah putus dan bertekstur lembut. 


\section{Kandungan Gizi}

Nilai uji kandungan gizi pada produk mie basah dapat dilihat pada Tabel 3, berikut:

Tabel 3. Hasil pengujian gizi pada produk mie basah

\begin{tabular}{|c|c|c|c|c|}
\hline Kode & & $\begin{array}{l}\text { Hasil } \\
\text { Uji }\end{array}$ & & \\
\hline & $\begin{array}{l}\text { Kadar } \\
\text { Air (\%) }\end{array}$ & $\begin{array}{l}\text { Kadar } \\
\text { Abu } \\
(\%)\end{array}$ & $\begin{array}{l}\text { Protein } \\
(\%)\end{array}$ & $\begin{array}{l}\text { Karbohidrat } \\
(\%)\end{array}$ \\
\hline No & 56,66 & 0,47 & 19,46 & 14,17 \\
\hline $\mathrm{N} 2$ & 56,93 & 0,5 & 24,85 & 15,86 \\
\hline
\end{tabular}

Berdasarkan Tabel 3 di atas, hasil uji laboratorium menunjukan kandungan gizi yang terdapat pada mie basah meningkat dengan penambahan tinta cumicumi (Loligo sp.) dibandingkan dengan mie basah tanpa tambahan tinta cumi-cumi (Loligo sp.).

Berdasarkan hasil dari pemilihan perlakuan terbaik metode indeks efektifitas, terlihat bahwa nilai kadar air mie basah tiap perlakuan adalah N0 56,66\%, dan N2 56,93\%. Nilai kandungan air tertinggi adalah $56,93 \%$, kadar air mie basah dengan penambahan tinta cumi-cumi (Loligo sp.) hasil penelitian ini menujukkan bahwa kadar air yang dihasilkan lebih tinggi dari penelitian Agusandi et al., (2013) sebesar $52,57 \%$.

Menurut penilitian Nadarajah (2017), tinta cumi-cumi (Loligo sp.) juga memiliki kandungan air sebesar $78,46 \%$. Hal ini dapat juga berpengaruh pada kandungan air pada mie basah dengan penambahan tinta cumi-cumi (Loligo sp.).

Kadar air mie basah dengan penambahan tinta cumi-cumi ini tidak jauh berbeda dengan mie basah menurut SNI, berdasarkan Standar Nasional Indonesia (01-2987-1992) kadar air mie basah yaitu sebesar 35-50\%, sedangkan menurut Winarno (2002), mie basah yang melalui pemasakan (perebusan) dengan air yang ditambahkan minyak sawit dapat memiliki kadar air mencapai sekitar $52 \%$, sedangkan mie basah mentah yang tidak melalui tahapan pemasakan memiliki kadar air sebesar $35 \%$.

Hasil penelitian yang dilakukan pada olahan mie basah dengan penambahan tinta cumi-cumi (Loligo sp.) kadar protein yang di hasilkan N0 19,46\%, dan N2 24,85\%. Hasil penelitian ini lebih tinggi dari penelitian sebelumnya yang dilakukan oleh Agusandi et al., (2013) kadar protein 7,109\%, dan Mukholik (1995) kadar protein $10,88 \%$. Hal ini dipengaruhi oleh kandungan terigu yang digunakan pada olah mie basah yang cukup tinggi yaitu $11 \%$, terigu yang digunakan adalah terigu segi tiga biru. Tingginya protein pada produk mie yang dihasilkan dipengaruhi oleh kandungan tinta cumi-cumi sebesar $14,52 \%$ (Nadarajah, 2017).

Kadar protein mie basah dengan penambahan tinta cumi-cumi ini telah memenuhi Standar Nasional Indonesia (SNI) 01-2987-1992 tentang mie basah yang menentukan bahwa kandungan protein dalam mie basah harus minimal $3 \%$. Tinta cumi-cumi mengandung 14 jenis asam amino terdiri dari asam amino non essensial yaitu asam glutamat, alanin, asam aspartat, glisin, serin, dan tirosin. Sedangkan kandungan asam amino essensial diantaranya yaitu lisin, isoleusin, valin, arginin, treonin, histidin, metionin. fenilalanin, dan leusin. Asam amino non esensial yang tertinggi pada hidrolisat protein tinta cumi-cumi yaitu asam glutamat dan alanin dengan nilai $0,35 \%$ dan $0,30 \%$, sedangkan asam amino essensial tertinggi yaitu fenilalanin dan leusin dengan nilai $0,23 \%$ dan $0,21 \%$ (Kurniawan, 2013).

Kadar abu memimiliki hubungan dengan kandungan mineral pada suatu bahan. Tujuan dari penentuan abu total adalah untuk menentukan baik tidaknya suatu proses pengolahan untuk mengetahui jenis bahan yang digunakan dan penetuan abu total berguna sebagai parameter nilai gizi bahan makanan (Sudarmadji et al., 2007).

Berdasarkan hasil dari pemilihan perlakuan terbaik metode indeks efektifitas, terlihat bahwa nilai kadar abu N0 0,5\%, dan N2 0,7\%. \%. Nilai kandungan kadar abu teringgi adalah $0,7 \%$, kadar abu mie basah hasil penelitian ini lebih tinggi dari kadar abu hasil penelitian Agusandi et al., (2013),sebesar 0,34\%, dan Hutasoit et al., (2015) sebesar 0,31\%.

Berdasarkan hasil dari pemilihan perlakuan terbaik metode indeks efektifitas, terlihat bahwa nilai kadar karbohidrat N0 14,17\% dan N2 15,86\%. Hal ini di dukung dengan penelitian (Hutasoir et.,al) bahwa mie interaksi pemanfaatan limbah tinta cumi-cumi sebagai pewarna alami mie basah dengan bahan pengikat berbeda berpengaruh nyata terhadap kadar karbohidrat tinta cumi-cumi, dimana kandungan karbohidrat yang dihasilkan $18,15 \%$ pada tingkat kepercayaan $95 \%$, Karbohidrat pada mie basah berasal dari tepung terigu, menurut Haryadi (1999), dalam setiap 100 gram tepung terigu mengandung karbohidrat sebesar $77,2 \%$. 


\section{Antioksidan}

Hasil pengujian antioksidan dapat di lihat pada Tabel 4, berikut :

Tabel 4. Hasil pengujian antioksidan pada produk mie basah.

\begin{tabular}{lll}
\hline Sampel & Regresi & $\mathrm{IC}_{50}$ \\
\hline N0 & $\mathrm{Y}=0,018 \mathrm{x}+11,393$ & $327,18 \mathrm{ppm}$ \\
N2 & $\mathrm{Y}=0,114 \mathrm{x}+13,874$ & $316,89 \mathrm{ppm}$ \\
Tinta cumi-cumi & $\mathrm{Y}=0,125 \mathrm{x}+16,513$ & $267,90 \mathrm{ppm}$ \\
\hline
\end{tabular}

Berdasarkan Tabel 4, diatas menunjukkan bahwa tinta cumi-cumi (Loligo sp.), mie basah dengan penambahan tinta cumi-cumi (Loligo sp.) mempunyai aktivitas antioksidan dengan $\mathrm{IC}_{50}$.Antioksidan merupakan molekul yang dapat memperlambat atau mencegah oksidasi. Aktivitas antioksidan yang terdapat pada tinta cumi-cumi (Loligo sp.), dan produk mie basah dengan penambahan tinta cumi-cumi dengan konsentrasi DPPH $\mathrm{IC}_{50}$ terdapat antioksidan didalamnya. Antioksidan dalam suatu produk dipengaruhi oleh adanya kandungan vitamin dan $\beta$ karoten. Antioksidan yang terdapat pada tinta cumicumi sebesar 267,90 ppm, sedangan pada produk mie basah dengan penambahan tinta cumi-cumi (Loligo sp.) N0 (327,18 ppm) dan N2 (316,89 ppm). Menurut Nadarajah (2017), dalam uji DPPH, ekstrak etanol tinta cumi telah menunjukkan aktivitas antioksidan sebesar $83,5 \%$. Tinta cumi ditemukan menjadi agen antibakteri yang kuat terhadap patogen yang diuji.

\section{KESIMPULAN}

Berdasarkan hasil penelitian dan pembahasan diatas maka dapat ditarik kesimpulan sebagai berikut:

1. Penambahan tinta cumi-cumi (Loligo sp.) dengan konsentrasi yang berbedah pada produk mie basah berpengaruh nyata terhadap uji sensori pada rasa, aroma, dan tekstur sedangkan pada warna tidak berpengaruh nyata. Sedangkan pada sifat fisik yang terdapat pada produk mie basah tidak mudah putus.
2. Terdapat pengaruh terhadap nilai kadar air, kadar protein, kadar abu, dan kadar karbohidrat pada produk mie basah. Terdapat aktivitas antioksidan pada produk mie basah dan tinta cumi-cumi (Loligo $\mathrm{sp}$.) dengan konsentrasi $\mathrm{IC}_{50}$

\section{DAFTAR PUSTAKA}

[AOAC] Association of Official Analytical Communities. 2005. Official Methods of Analysis of AOAC International. Ed ke-18, Rev ke-2. Maryland (US): AOAC International

Agusandi, Agus Supriadi, Shanti Dwita Lestari. $2013 . \quad$ Pengaruh penambahan tinta cumi- cumi (Loligo sp.) Terhadap kualitas nutrisi dan penerimaan sensoris mie basah. Jurnal fishtech. 2(1): 22-37.

Dian Monica H, Syahrul, N. Ira Sari. 2015. Kajian pemanfaatan limbah tinta cum- cumi (Loligo sp.) sebagai pewarna alami mie basah dengan bahan pengikat berbeda terhadap penerimaan konsumen. JOM Oktober 2015

De Garmo ED, W.G. Sullivan and J. R. Canada. $1984 . \quad$ Engineering Economis.Mc Millan Publishing Company. New York.

Direktorat Jenderal Perikanan Tangkap. 2011. Peta Keragaan Perikanan Tangkap di Wilayah Pengelolaan Perikanan Republik Indonesia (WPP-RI). Kementerian Kelautan dan Perikanan, Jakarta. 68 hal.

Haryadi. 1999. Teknologi Pengolahan Pangan Nabati. PAU. Pangan dan Gizi. IPB. Bogor. 
Kurniawan. 2013. Hidrolisat Protein Tinta cumi-cumi (Loligo sp) dengan Enzim Papain. Skripsi. Teknologi Hasil Perikanan. Fakultas Pertanian. Universitas Sriwijaya. Indralaya.

Mukholik. 1995. Pengaruh larutan tinta cumi- cumi dan suhu perebusan terhadap air rebusan cumi-cumi. [Skripsi]. Fakultas Perikanan dan Ilmu Kelautan. Institut Pertanian Bogor.

Nadarajah, Sri. Et., al. 2017. Theperapeutic Significance of Loligo vulgaris (Lamarck, 1798) ink extract: $A$ biomedical approach. Pharmacognosy

Research, suppl, Supplement ; Mumbai vol 9, Iss 5 (2017).

Okuzumi M dan Fujii T. 2000. Nutritional and Functional Properties of Squid and Cuttlefish. Japan: National Cooperative Association of Squid Processors.

Pribadi Al 2011. Skripsi kandungan gizi dan karakteristik mi basah dengan penambahan ikan lele dumbo (Clarias gariepinus). Skripsi S1. Universitas Sriwijaya. Indralaya.

Sudarmadji. S., Haryono, B., Suhardi. 2007. Analisis Bahan Makanan dan Pertanian. Liberty. Yogyakarta.

Sudjoko B. 1988. Cumi-cumi (Cephalopoda Molusca) Sebagai Salah Satu Makanan dari Laut. Oseana, Jakarta, hlm $97-107$.

Susrini (2005). Index efektifitas; suatu pemikiran tentang alternatif untuk memilih perlakuan terbaik pada penelitian pangan. Edisi ketiga dengan Perbaikan, Program Studi Teknologi Hasil Ternak, Fakultas Peternakan, Universitas Brawijaya, Malang.

Winarno FG. 1992. Kimia Pangan dan Gizi. Jakarta: PT Gramedia.

Winarno. 1997. Kimia Pangan dan Gizi. Jakarta: P.T Gramedia Pustaka Utama.

Winarno. 2004. Kimia pangan dan gizi. Jakarta: PT Gramedia Pustaka Utama 